\title{
Vulnerability of Southern Plains agriculture to climate change
}

\author{
Jean L. Steiner ${ }^{1}$ - David D. Briske ${ }^{2}$ David P. Brown ${ }^{1}$ • \\ Caitlin M. Rottler ${ }^{1}$
}

Received: 22 November 2016 / Accepted: 31 March 2017 / Published online: 13 April 2017

(C) The Author(s) 2017. This article is published with open access at Springerlink.com

\begin{abstract}
Projections of greater interannual and intrannual climate variability, including increasing temperatures, longer and more intense drought periods, and more extreme precipitation events, present growing challenges for agricultural production in the Southern Plains of the USA. We assess agricultural vulnerabilities within this region to support identification and development of adaptation strategies at regional to local scales, where many management decisions are made. Exposure to the synergistic effects of warming, such as fewer and more intense precipitation events and greater overall weather variability, will uniquely affect rain-fed and irrigated cropping, high-value specialty crops, extensive and intensive livestock production, and forestry. Although the sensitivities of various agricultural sectors to climatic stressors can be difficult to identify at regional scales, we summarize that crops irrigated from the Ogallala aquifer possess a high sensitivity; rangeland beef cattle production a low sensitivity; and rain-fed crops, forestry, and specialty crops intermediate sensitivities. Numerous adaptation strategies have been identified, including drought contingency planning, increased soil health, improved forecasts and associated decision support tools, and implementation of policies and financial instruments for risk management. However, the extent to which these strategies are adopted is variable and influenced by both biophysical and socioeconomic considerations. Inadequate local- and regional-scale climate risk and resilience information suggests that climate vulnerability research and climate adaptation approaches need to include bottom-up approaches such as learning networks and peer-to-peer communication.
\end{abstract}

This article is part of a Special Issue on "Vulnerability Assessment of US Agriculture and Forests developed by the USDA Climate Hubs" edited by Jerry L. Hatfield, Rachel Steele, Beatrice van Horne, and William Gould.

Jean L. Steiner

jean.steiner@ars.usda.gov

1 US Department of Agriculture, Agricultural Research Service, Grazinglands Research Laboratory, 7207 W. Cheyenne Street, El Reno, OK 73036, USA

2 Department of Ecosystem Science and Management, Texas A\&M University, Centeq Building, Room 130C, MS 2120 TAMU, College Station, TX 77843, USA 


\section{Introduction}

Climate is a key driver for all ecological and economic systems; therefore, climate change introduces additional uncertainty and vulnerability into these systems (IPCC 2014). Agricultural vulnerability to climate change is well documented at global and national scales (e.g., Walthall et al. 2012; Hatfield et al. 2011; Izaurralde et al. 2011; Lal 2016; Porter et al. 2014). However, it is essential to elucidate vulnerabilities in a way that helps identify adaptation strategies at regional to local scales where management decisions are made. The objective of this assessment is to identify key vulnerabilities of agriculture to climate change in context of the Southern Plains region of the USA, taking a "bottom-up" approach (Noble et al. 2014), whereby practical and efficient adaptation strategies for specific key production systems are proposed. Additionally, this analysis focusing on vulnerability of key agricultural sectors, such as rain-fed and irrigated cropping, highvalue specialty crops, extensive and intensive livestock systems, and forestry, may provide a useful framework to assess vulnerability in similar agro-ecoregions of the world.

\section{Agriculture and climate in the Southern Plains}

The Southern Plains is primarily characterized by grassland, cropland, and forest land (US Geological Survey (USGS) 2011). In 2012, the regional value of agricultural activity exceeded $\$ 59$ billion (National Agricultural Statistics Service (NASS) 2014), with livestock accounting for about $58 \%$ of the total. Commodities that exceeded $\$ 1$ billion across the region (Kansas, Oklahoma, Texas) include wheat, corn, horticultural crops, cotton, hay and forages, sorghum, soybean, beef cattle, poultry and eggs, dairy, and swine (Table 1). Forests occupy a smaller land area, but still account for 27 million acres and support numerous ecosystem services both internal and external to the region.

Agriculture in the Southern Plains is water limited, with average evaporation exceeding average precipitation in each month of the year (Stewart and Steiner 1990). Even the humid eastern portion of this region experiences regular drought that impacts agricultural systems,

Table 1 Monetary value of major crop and livestock commodities in the Southern Plains in 2012

\begin{tabular}{|c|c|c|c|c|}
\hline Commodity & Kansas & Oklahoma & Texas & Southern Plains \\
\hline \multicolumn{5}{|l|}{ Billion \$ } \\
\hline Crops & 6.984 & 1.876 & 7.367 & 16.227 \\
\hline Wheat & 2.474 & 0.946 & 0.618 & 4.038 \\
\hline Corn & 2.297 & 0.203 & 1.454 & 3.954 \\
\hline Horticultural $^{\mathrm{a}}$ & 0.093 & 0.268 & 1.738 & 2.101 \\
\hline Cotton & - & 0.052 & 1.619 & 1.671 \\
\hline Hay & 0.359 & 0.271 & 0.958 & 1.588 \\
\hline Sorghum & 0.579 & 0.034 & 0.743 & 1.356 \\
\hline Soybean & 1.102 & 0.048 & 0.037 & 1.187 \\
\hline Livestock & 11.477 & 5.254 & 18.009 & 34.740 \\
\hline Beef cattle & 10.153 & 3.403 & 13.013 & 26.569 \\
\hline Poultry, eggs & 0.088 & 0.961 & 2.325 & 3.374 \\
\hline Dairy & 0.482 & 0.164 & 1.698 & 2.344 \\
\hline Swine & 0.697 & 0.656 & 0.239 & 1.592 \\
\hline Total agriculture & 18.461 & 7.130 & 25.376 & 59.966 \\
\hline
\end{tabular}

Source: National Agricultural Statistics Service (2014)

${ }^{a}$ Includes vegetables, fruits, nuts, nursery, greenhouse, floriculture, and sod 
streamflow, and reservoir recharge. Many Southern Plains soils have been degraded as characterized by erosion and loss of soil organic matter. Additionally, many cropping systems expose bare soils to intense precipitation events and potential erosion. High runoff results in low water use efficiency of rain-fed cropping and grazing systems and contributes to water quality concerns.

The Ogallala aquifer supports irrigated crops in western Kansas and the panhandles of Oklahoma and Texas, but demands have exceeded recharge rates, leading to depletion of the aquifer (McGuire 2011). Surface-water irrigation is also vital to the region's agriculture, including in the Rio Grande valley, which supports major vegetable and citrus production. Projections for a warming and drying climate with more extreme weather events will increase vulnerability of agriculture in the Southern Plains (Steiner et al. 2015). Water-related challenges will be further complicated by differing water policies among the three states, across Tribal governments, and among different water conservation districts in Kansas and Texas (Peck 2007).

\section{Vulnerability framework}

Vulnerability assessments are well-established frameworks that have been adopted by the Intergovernmental Panel on Climate Change (IPCC 2014) to evaluate impacts of climate change (Noble et al. 2014). Vulnerability describes the degree to which a system is likely to experience harm due to exposure to hazards (i.e., disturbance or stressor) (IPCC 2014) and is comprised of interrelated components: exposure, sensitivity, and adaptive capacity (Adger 2006). Vulnerability of agricultural enterprises to climate change is determined by interacting social and ecological variables, including the extent to which climate change occurs; the exposure and sensitivity of a particular system to climatic stressors; and the adaptive capacity of systems, institutions, humans, and other organisms to adjust to potential damage, take advantage of opportunities, or respond to consequences (IPCC 2014). Vulnerability assessments simultaneously address these three components and their interactions (Fig. 1). It is critical that vulnerability assessments look beyond climate exposure and economic sensitivity in order to emphasize opportunities to develop adaptive capacity, implement adaptation practices (Joyce et al. 2013), and minimize overreliance on short-term responses (Nelson et al. 2010).

\subsection{Exposure}

Exposure occurs when particular agricultural enterprise is active during the period when a climate stressor is present (Anandhi et al. 2016). Regional temperatures are projected to rise, with up to 30 additional days annually of temperatures above $95^{\circ} \mathrm{F}$ (Kunkel et al. 2013a). Parts of the region may experience temperatures exceeding $100^{\circ} \mathrm{F}$ up to 60 days annually by 2065. Prolonged periods of high temperatures in the Southern Plains have previously coincided with drought, such as in Texas in 2011 (Hoerling et al. 2013). Projected increases in maximum temperatures will intensify evaporative demand and may increase the risk of significant wildfire events. Minimum temperatures will be elevated (Shafer et al. 2014), increasing the number of heating degree days each year and extending the freeze-free season by up to 30 days (Kunkel et al. 2013a). While the extended growing season could benefit some regions, the actual number of growing days will likely decrease when water deficits are considered (Mora et al. 2013).

Projected changes in regional precipitation are more complex and less certain, with climate model simulations showing a range of potential outcomes into the middle and late twenty-first 
Fig. 1 Factors affecting vulnerability of agro-ecosystems as determined by exposure to the climate stressor, sensitivity of the system, and the adaptation or adaptive capacity to act to minimize negative impacts

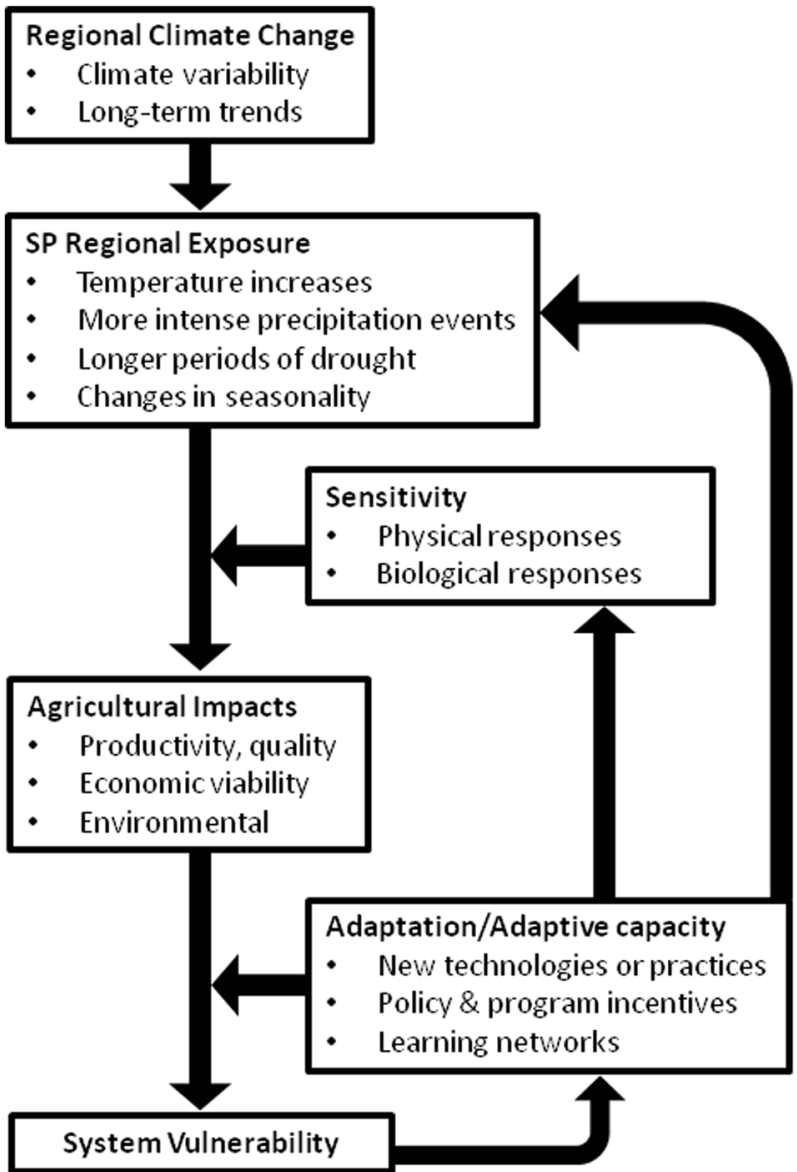

century. Large parts of Oklahoma and Texas are projected to experience longer droughts, with the number of consecutive dry days increasing by up to 5 days (Shafer et al. 2014). As a result, regional droughts - particularly "flash droughts" (Otkin et al. 2016) - may increase in number and intensity. When precipitation does occur, it is likely to be more intense, with a $10-15 \%$ increase in maximum 1-day precipitation totals across the region by 2065 (Shafer et al. 2014). Heavier downpours will present additional management challenges due to flash flooding and increased soil erosion (Ojima et al. 2015). The frequency of precipitation greater than 2 in. may increase markedly in Kansas and Oklahoma, but decrease in central and southern Texas (Kunkel et al. 2013b). Warmer temperatures will likely reduce the number and intensity of snow events, particularly in southern portions of the region.

Although the concept of exposure is straightforward, there is no widely accepted method for relating indices of climate stressors to the magnitude of exposure for various agricultural enterprises. Anandhi et al. (2016) illustrated a framework for quantifying exposure using a number of climate indices that impact cropping systems of Kansas. Given that precise projections of exposure are currently not possible, multiple adaptation strategies and options are needed to address diverse needs of managers and enterprises (Briske et al. 2015). 


\subsection{Sensitivity}

The sensitivity of plant and animal species to climatic stressors changes with phases of the life cycle. A plant may be mildly sensitive to high-temperature stress during vegetative growth, but highly sensitive to high temperature during reproductive growth. Animals may exhibit minimal sensitivity to water stress during periods with moderate temperatures, but be highly sensitive to limited water during periods of high-temperature stress.

Sensitivity of agricultural enterprises is determined by unique exposures to climate stress, sensitivity of specific production systems to these stressors, and the ability of managers to implement adaptation strategies in a timely manner. Limited enterprise diversity and flexibility are often associated with high sensitivity. High sensitivity may originate from multiple causes, including limited property size and financial capital and insufficient strategic skills and environmental awareness (Joyce et al. 2013; Noble et al. 2014). Many of these causes are associated with low adaptive capacity as discussed below.

\subsection{Adaptive capacity and adaptive management}

Adaptation in human systems is the process of moderating or avoiding harm or exploiting beneficial opportunities by adjusting to actual or expected climate change. Key components of adaptive capacity include access to economic resources, technical options, and information; management skills; and existence of effective institutions and policies (Noble et al. 2014; Howden et al. 2007; Engle 2011). Developing capacity to implement strategies that avoid stress or reduce system sensitivity can minimize vulnerability. Knowledge of climate change is under-utilized in adaptation, because procedures for incorporating climate information into decision making have not been adequately developed (Marshall 2010; Joyce et al. 2013). This has contributed to a gap between the current state of the system and a system that could minimize adverse impacts of climate change (Noble et al. 2014). This condition is generally described as an adaptation "deficit" or as a "drought trap" in rangeland livestock systems (Joyce et al. 2013).

The consequences of adaptive management may modify prevailing conditions and subsequent adaptation options (Fazey et al. 2010). This emphasizes flexibility as a central feature of enterprises that adapt successfully to climate change (Pelling 2011). Adaptive capacity is highly diverse among agricultural producers in terms of their ability to plan, recognize, and manage risk, and to adopt and implement adaptation strategies (Marshall 2010; Briske et al. 2015). Therefore, an array of flexible and cost-effective adaptation strategies are needed that can address the varied sensitivities and adaptive capacities within agricultural systems. Policies, strategies, and incentives designed to support climate adaptation will need to consider existing adaptive capacity of individuals or groups and the region-specific climatic impacts that are anticipated (Briske et al. 2015).

\section{Agricultural sensitivities to climate change in the Southern Plains}

\subsection{Crops (Table 2)}

Crops are exposed to a wide range of intraannual and interannual climate stressors to which they are highly sensitive, both independently and in concert. The dominant rain-fed crop, 
winter wheat, is a cool season crop vulnerable to drought, extreme precipitation, increasing temperatures, and changes in seasonality. Establishment of winter wheat is also sensitive to drought, which can reduce fall forage production for livestock. Tillage following wheat harvest can expose the soils to intense rainfall events during the spring and summer months. Warming temperatures can accelerate phenologic development of winter wheat, leaving it susceptible to late frosts after head emergence. Additionally, warm spring temperatures, when combined with dry conditions, can shorten the grain-filling period and reduce wheat yields. In a global assessment, Liu et al. (2016) found that for each $1{ }^{\circ} \mathrm{C}$ temperature increase, wheat yield is projected to decrease by $4.1-6.4 \%$, with the greatest decreases expected in the warmest regions. Vocke and Ali (2013) reported that, due to these multiple climate stresses, Texas and Oklahoma have had lower and more variable yields of hard red winter wheat than the rest of USA. Additionally, use of wheat for forage as well as a grain crop, coupled with frequent drought, resulted in a substantially lower ratio of harvested to planted acreage in the Southern Plains compared to the rest of the nation. Rain-fed summer crops are highly sensitive to high temperatures, drought, and extreme rainfall events that can result in erosion and runoff, soil crusting, and physical crop damage from hail.

Corn and other feed crops are the primary irrigated crops in Kansas, Oklahoma, and the Texas panhandle, while irrigated cotton dominates further south (Ojima et al. 2015). The region also supports a bioenergy industry, and the grain crop-energy-feedlot sectors are tightly linked. Irrigation reduces exposure to drought from the perspective of crop productivity, but drought and high temperatures increase irrigation requirement and therefore production cost. Additionally, increased pumping during drought exacerbates the long-term depletion of regional groundwater supplies, which has wide-ranging impacts on the region's social, economic, and ecological systems (Wang et al. 2011).

Horticultural crops including sod, tree crops, vegetables, and other specialty crops occupy relatively small areas of land in the Southern Plains, but provide high economic returns and employment. Because of the high capital investment as well as cost of establishing perennial and tree crops, these systems are particularly sensitive to severe weather such as hail, high winds, ice events, and tornados. Specialty crops are often sensitive to high and low temperatures, which can impact quality as well as quantity of production and reduce market price.

\subsection{Livestock (Table 3)}

All phases of beef cattle production - cow/calf, stocker grazing, and finishing - are regionally important, comprising up to $68 \%$ of agricultural production value in parts of the Southern Plains (McBride and Mathews 2011). Extensive grazing systems are based on a diversified land use that includes native grasslands, a variety of perennial pastures, and annual forage crops. Drought and rising temperatures are primary climate concerns for beef cattle production, affecting forage availability and quality, water supply, and associated heat stress on cattle (Polley et al. 2013; Ojima et al. 2015).

Climate stress results in lower forage quantity and quality, and animal intake will be reduced by lower-quality forage, higher temperatures, and more frequent intense heat (CCSP 2008). High temperatures combined with water deprivation can result in livestock losses on rangelands (Kay 1997; Silanikove 2000). Dry springs and ponds during drought require that livestock travel greater distances for water or that additional water sources be provided. Additional travel distances to water affect livestock distribution and the portion of the pasture that is grazed (Kay 1997; Parsons et al. 2003). Livestock concentration near water and in 


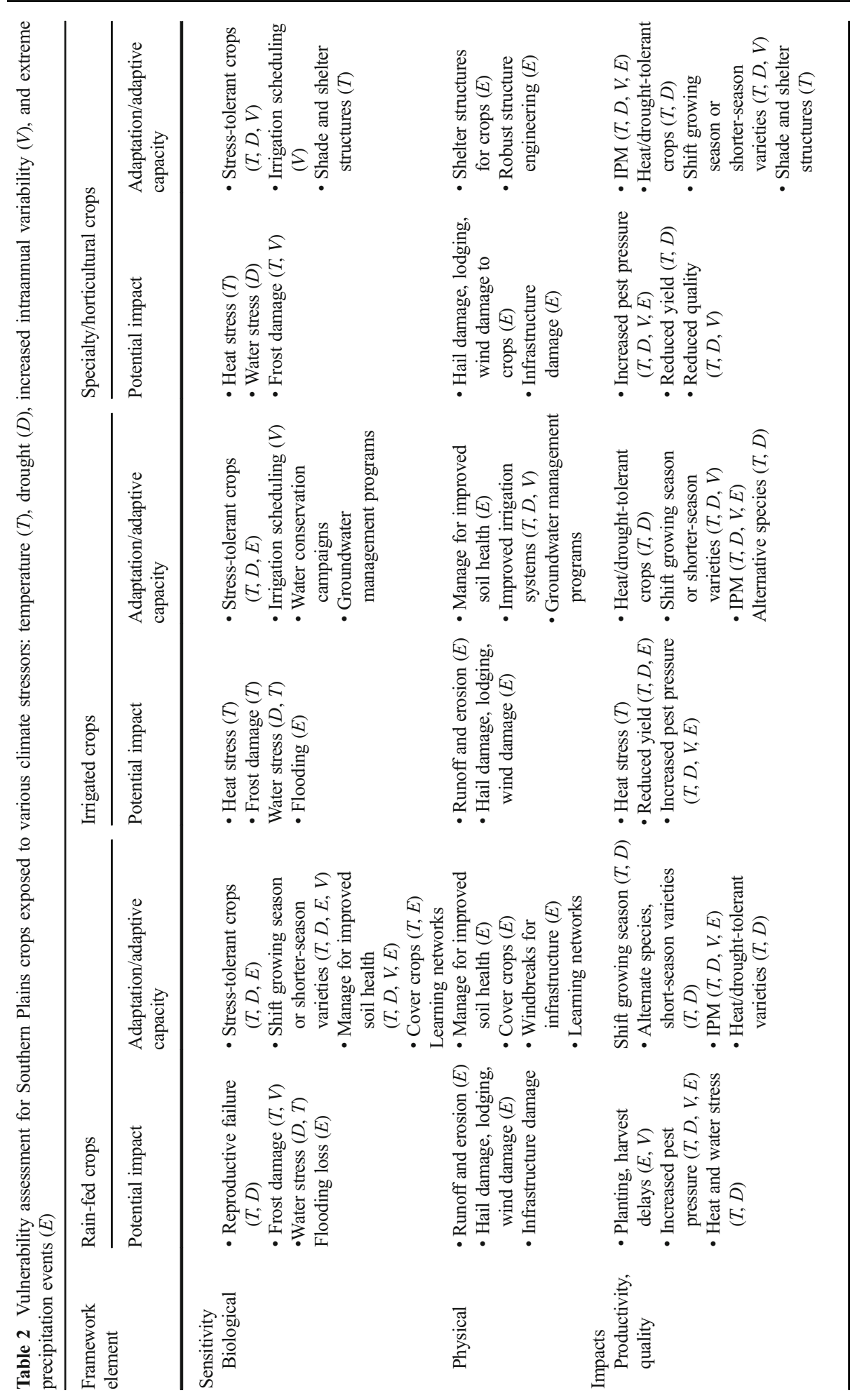




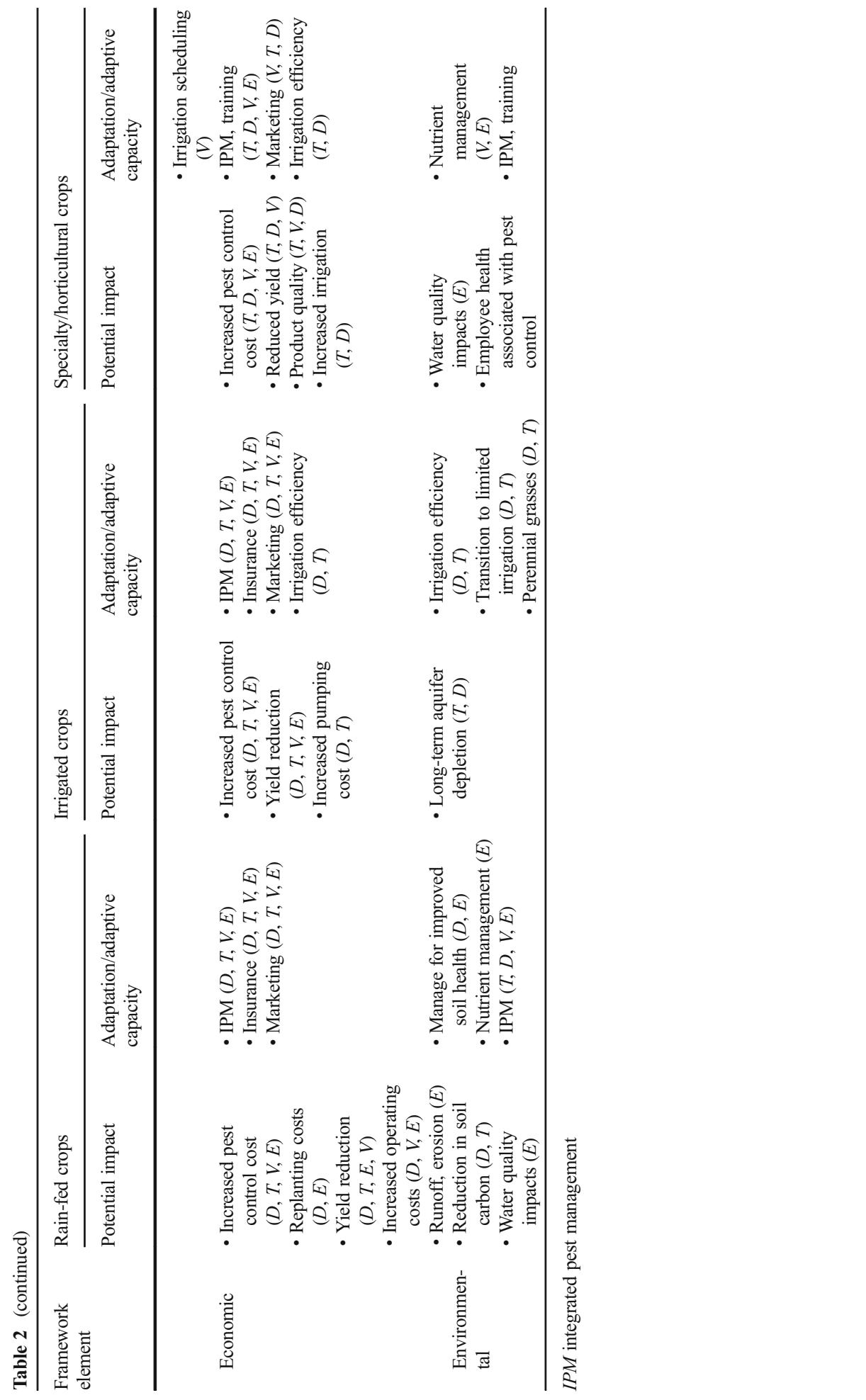




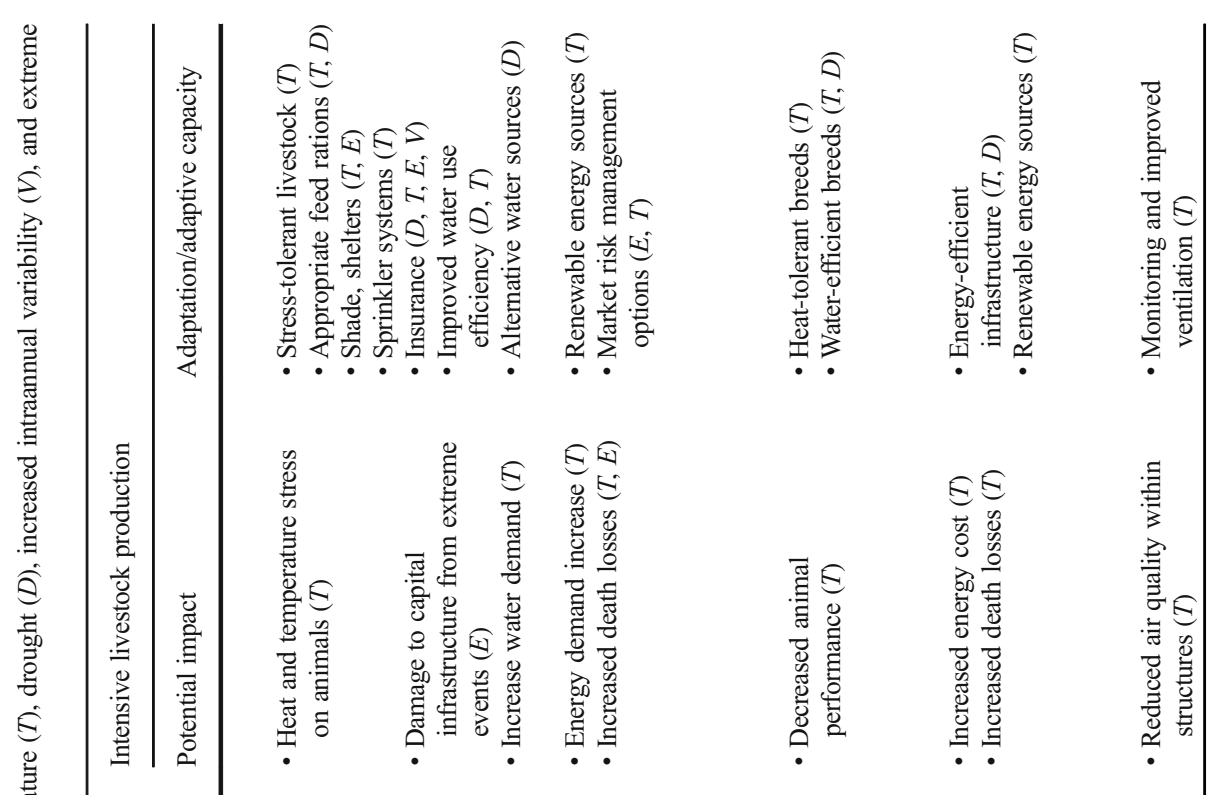

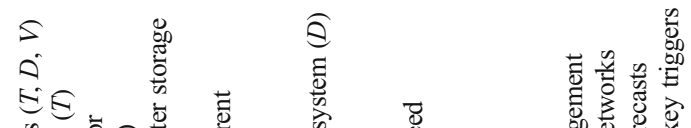

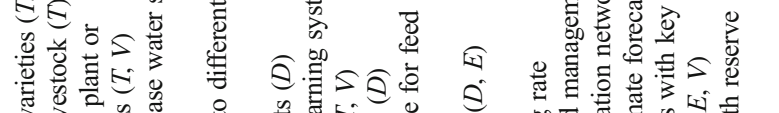

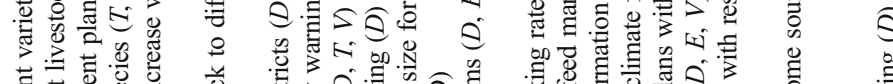

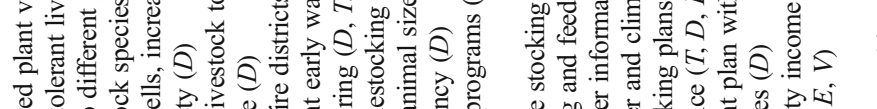

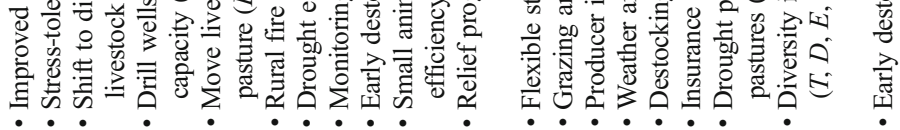

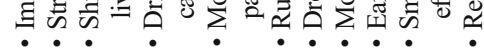

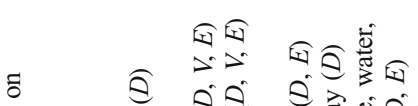

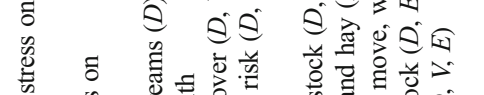

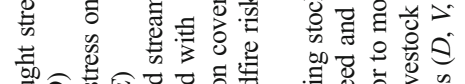

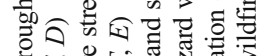

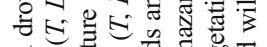

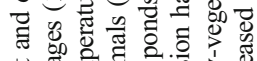

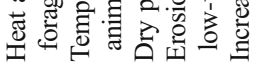
寻芯: 崩

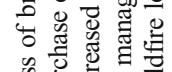

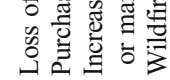

ริิ

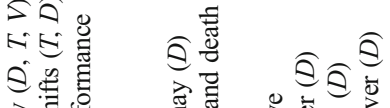

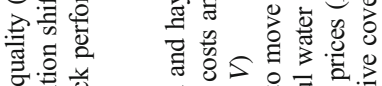
대유

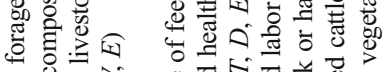

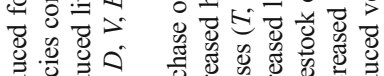

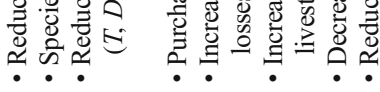

焉

氜

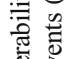

焉

$>$

m.

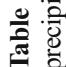

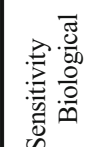

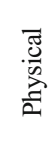

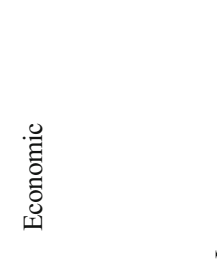

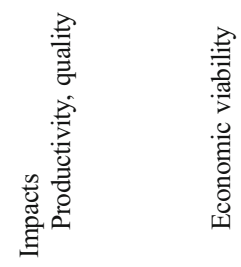

플 


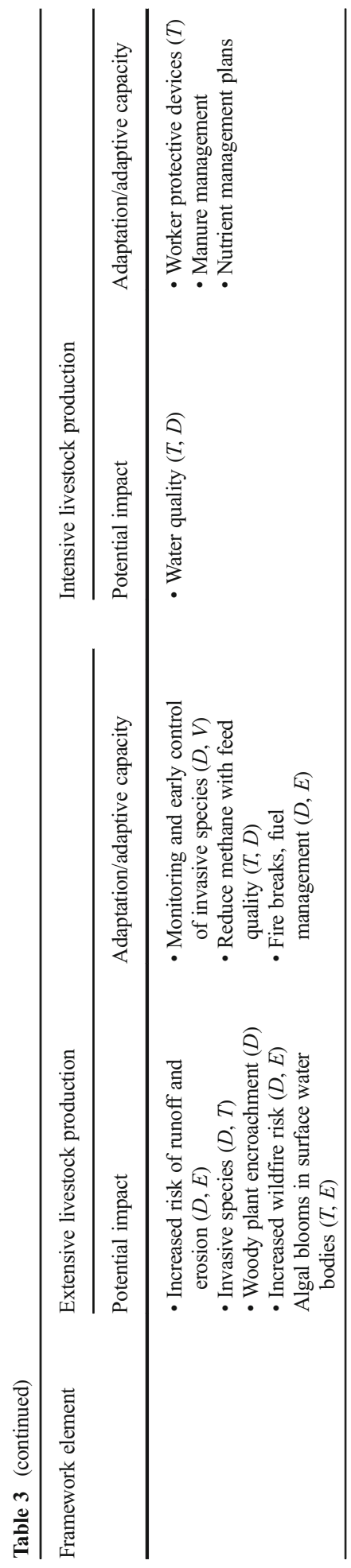

勿 Springer 
riparian areas may produce adverse effects on soils, plant communities, and forage production and impair water quality.

Warming and drying, especially in southern portions of the region, are anticipated to modify plant community composition and vegetative cover, including an increase in woody plant density and cover or die-off of some species during extreme drought (Briske et al. 2015). For example, eastern redcedar (Juniperus virginiana) was the only southern savanna dominant plant species in which neither survival nor aboveground mass was adversely affected by warming and intensified summer drought (Volder et al. 2013). Additionally, the growth of eastern redcedar has increased in response to warming. These results suggest that, due to greater drought tolerance and a positive response to warming, juniper encroachment into grassland is very likely to accelerate in response to climate change (Volder et al. 2013), resulting in reduced forage availability, degraded habitat for a number of wildlife species, and increased human health impacts associated with allergens (Van De Water and Levetin 2001).

Substantial decreases in historical stocking density have occurred throughout Texas, with the sharpest decline beginning during the mid-twentieth century (Wilcox et al. 2012). The extent of reduction has varied, but approached $75 \%$ in the Trans-Pecos and Edwards Plateau regions, with woody plant encroachment likely contributing to these declines. An increasing occurrence of climatic extremes, specifically successive wet and dry seasons or years, will likely increase frequency and extent of wildfires in grasslands and necessitate greater attention to fuel management and safeguards to human life and property (Polley et al. 2013).

Beef cattle feedlots, swine, and dairy operations are largely situated in semi-arid western portions of the region and depend on water supplied by the Ogallala aquifer. Energy requirements and costs along with animal health and productivity are sensitive to high-temperature exposure in these sectors. Heat stress can be fatal for cattle in feedlots, especially for those fed large quantities of high-quality feeds (Hahn 1997; Howden et al. 2007). Dairy production is also reduced by high-temperature stress (Key et al. 2014).

Poultry production is important in eastern Oklahoma and Texas. This industry interfaces with beef cattle production because poultry litter is commonly applied to pastures as a nutrient source (Waldrip et al. 2015). In some cases, over-fertilization has led to increased nutrient runoff from fields, which is exacerbated by intensification of some precipitation events. This has resulted in nutrient enrichment of watersheds and has caused cross-state conflict associated with water quality in water supply and recreation associated with reservoirs and scenic rivers (Layden 2014). Operating costs and poultry health are sensitive to high-temperature extremes.

\subsection{Forests}

Forest species in the Southern Plains are generally at the margins of their distribution, and are therefore more sensitive to climatic change and extreme events than more centrally distributed forests. For example, the 2011 drought killed more than 300 million rural trees across Texas (Moore et al. 2016). While predictions of future precipitation vary among different climate models, most agree that climate change is likely to result in increased temperatures with associated increases in evapotranspiration and water demand (Sun et al. 2008). In turn, increased water use by trees will reduce streamflow, which could negatively affect aquatic habitats and biodiversity regardless of changes in annual precipitation. Newly planted forests are sensitive to drought, exhibit reduced growth rates, and decreased resistance to insects and disease, which may negatively affect wildlife habitat and populations (Dinon et al. 2013). Droughts and high temperatures also pose major fire risks, especially where drought-induced 
tree mortality has increased fuel loads. Finally, the southern pine beetle (SPB) has long been an episodic problem in eastern Texas, with outbreaks occurring across a range of environmental conditions (McNulty et al. 1998). Ayres and Lombardero (2000) predicted that SPB outbreaks will become more numerous with climate change as a result of longer breeding seasons and potential production of more insect generations each year.

\section{Adaptation and adaptive capacity of Southern Plains agriculture}

Multiple adaptation strategies have been developed to mitigate impacts of intraannual and interannual weather variability on agricultural production, especially for drought management. The challenge for adaptation planning is to select, implement, and effectively manage appropriate adaptation at the appropriate time. Additionally, a better understanding of climate patterns and signals that impact agricultural resource management (Baumhardt et al. 2016; Mauget et al. 2014a, b; Stout and Lee 2003) improved modeling frameworks for evaluation of alternative tactics and strategies (Ahuja et al. 2007), and information-based management tools (Franzen et al. 2016) are needed to provide managers with increased knowledge to inform management decisions.

\subsection{Adaptation planning for cropping systems}

There is increasing appreciation of the critical role that soils can play to reduce system vulnerability to climate change (Paustian et al. 2016; Brown and Herrick 2016). While carbon stock is declining under most croplands, many producers have successfully increased soil organic matter by changing disturbance practices and diversifying and increasing plant growth, leading to improved aggregation, water infiltration and holding capacity, and nutrient cycling (Acosta-Martínez et al. 2014; Jin et al. 2013; Lehman et al. 2015; Mbuthia et al. 2015; Lehman et al. 2015). This reduces vulnerability of landscapes and agricultural systems to intensifying climatic variability. The USDA Soil Health Initiative, in conjunction with conservation districts, university extension, non-profit organizations, and producers, promotes four key principles to rebuild the soil resource: (1) maintain a vegetative soil cover, (2) minimize soil disturbance, (3) promote plant growth throughout the year to feed the soil, and (4) diversify and rotate crops and cover crops to the extent possible. Increasing soil organic matter, structure, and function is one of the most effective ways to reduce vulnerability of crop and livestock systems across all regions, and the need for such adaptive approaches is great in the Southern Plains (Mbuthia et al. 2015).

Crops are exposed to both dry and wet conditions during sensitive periods such as the planting season or reproductive growth phases. To reduce impacts of exposure and sensitivity to climate stresses, producers are adopting reduced tillage practices, expanding use of cover crops, diversifying crop rotations, and using new varieties or species, among other technologies. Vitale et al. (2014) reported higher net returns in more diversified cropping systems. However, in drier parts of the region, cover crops may excessively deplete stored soil water needed by the subsequent cash crop (Nielsen et al. 2016). Conservation and farm risk management programs as well as extension and farmer learning networks can increase adaptive capacity and accelerate adoption of appropriate adaptive practices and technologies.

Adaptation approaches for irrigated agriculture to address climate change and limited water supply include new crop varieties (Burow et al. 2014a), lower-water-requirement species (Xue 
et al. 2014), and more efficient irrigation management (Baker et al. 2013; Conaty et al. 2012). Local water management districts, which exist in some areas of the Southern Plains, can help build adaptive capacity of producers and rural communities. Because of high exposure, high sensitivity, and high economic impact of climate stresses, insurance of specialty crops and their associated infrastructures is important to economic viability of these systems. Additionally, improved varieties and cost-effective shelter systems, such as hoop houses, provide adaptive technologies for high-value crops.

Ongoing breeding programs for crops need to increase drought, heat, and flooding tolerance in order to account for changing hydrologic and temperature dynamics (Burke and Chen 2015; Wang et al. 2014; Emendack et al. 2014). New crop species require extensive agronomic research and development of production and marketing infrastructure within a region. Increased adoption of integrated pest management practices will be required for early detection of and flexible responses to increased or new pest pressures (Backoulou et al. 2014; Nansen and Elliott 2016). For forests and tree-based systems, silvicultural management, including thinning and reduction of tree density, can be used to reduce tree mortality and fire risk (Dinon et al. 2013), but may need to become more frequent and aggressive in response to climate change.

\subsection{Grazing land livestock}

This assessment primarily emphasizes "within ranch gate" strategies, and does not address broader issues of livestock transportation, meat processing, and cost and availability of water and energy for these enterprises. Adaptive strategies for extensive livestock production involve changes in grazing management, livestock breeds or species, pest management, and enterprise structure, and even geographic re-location of livestock production systems to contend with impacts of climate change in the region (Table 3). These strategies vary greatly in their extent of modification, timing of implementation, specificity of impact, and potential for success or failure (Briske et al. 2015). Adaptive capacity of enterprise managers - which is often overlooked - is as important to effective adaptation planning as is the intensity and duration of climatic variability. Some adaptation strategies require substantial modification of production enterprises, and many managers may need to develop additional skills and may require access to financial capital and technical support to implement them. The projection of climate conditions that have not previously been experienced by the agricultural sector in the Southern Plains underscores the need for development and experimentation with diverse adaptation strategies.

The variety and combinations of livestock adaptations to increasing climatic variability have been organized in multiple ways (Noble et al. 2014) and can be characterized using three broad categories - human, enterprise, and social — as described by Joyce and others (2013). The human category addresses climate change awareness, risk tolerance or aversion, emotional flexibility, and capacity for innovation. These attributes are not well quantified for regional agricultural enterprise managers, but they are critical to both development and implementation of adaptations (Marshall 2010). Enterprise adaptations primarily emphasize flexibility of feed sources and adjustment of livestock herd size and composition to match forage supply with demand. Specific adaptations include reserve forage strategies, livestock supplementation to offset reductions in forage quality, combined stocker and cow-calf herds, and integrated livestock-cropping systems (Howden et al. 2007; Joyce 2013). Heat stress maps and alerts provide producers with information that is useful for mitigating animal stress during heat 
waves (Brown-Brandl et al. 2005; Eigenberg et al. 2005). Social adaptations are those that extend beyond the enterprise to influence both human and enterprise adaptations described above and include learning networks, social organizations supporting enterprise flexibility, and policies that incentivize development and implementation of adaptation strategies.

Conservative stocking rates have long been recognized as a viable strategy to maintain economic viability and ecological integrity of grazing lands. However, projections for increasing climatic variability suggest that flexible stocking strategies may require greater consideration. Stockers can be used to supplement the base cow herd to harvest additional forage production in wet years, and they provide an effective way to reduce animal numbers in dry years. Flexible grazing management based on combined cow-calf and yearling operations can produce greater economic returns than a set conservative strategy (Torell et al. 2010; O'Reagain et al. 2011). However, this adaptation introduces greater enterprise complexity and requires additional labor, buyers and sellers for stocker animals, and financial commitments that exceed the adaptive capacity of some managers in the absence of technical and financial support.

Alternative livestock species represent another potential adaptation to warming climates. It has been recognized that Bos indicus cattle (e.g., Brahmans) are more tolerant to heat stress than Bos taurus breeds (English and Continental) (Hoffmann 2010; O’Neill et al. 2010). An increase in Brahman and Brangus relative to Angus cattle breeds in hotter regions of Texas suggests that managers have recognized the value of this adaptation (Zhang et al. 2013). Smaller ruminant livestock, e.g., sheep and goats, are more heat tolerant, require less water, and can consume a greater diversity of plant species than cattle and may be better suited to future climates in the Southern Plains (Polley et al. 2013).

\section{Conclusions}

Agricultural production in the Southern Plains has always been challenged by climate. Projections for increasing interannual and intrannual climate variability, including increasing temperatures, longer and more intense drought periods, and more extreme precipitation events, present even greater challenges for the agricultural sector in the future. We offer the following considerations to increase our understanding of, and ability to minimize, agricultural vulnerability in the Southern Plains of the USA:

- Increasing climatic variability will increase management uncertainty throughout the agricultural sector. Intraannual variability may pose an even greater challenge than interannual variability because of limited capacity to minimize these rapidly occurring risks.

- Economic viability may be more sensitive to increased climatic variability than agricultural production (Thamo et al. 2017), because increasing costs of production may reduce profitability even in cases where long-term production potential is maintained. Additionally, regional droughts can cause market drops, as when large numbers of livestock are sent to market in response to regional forage limitations. Similarly, bumper crops during wet years can cause drops in regional market prices.

- Irrigated agriculture faces increasing challenges, particularly in the Ogallala aquifer region, where it is projected that pumping costs will limit agricultural use by about 2030 (Wang et al. 2011). Growing water use by the energy sector as well as increasing municipal demand will further compete with agricultural requirements. 
- Rangeland beef cattle production may more effectively reduce agricultural sensitivity to climatic impacts compared to cropland beef cattle production (Weindl et al. 2015). Diverse perennial grass species possess greater drought resistance and responsiveness to elevated $\mathrm{CO}_{2}$ than annual crops and are less dependent upon irrigation, fertilizer, and other annual inputs.

- Shifts from crop monocultures toward diversified crop-livestock systems may have potential resource- and cost-efficiency advantages based on strong synergies among systems and diversified income sources (Weindl et al. 2015).

- Although multiple strategies are available for reducing exposure and sensitivity and expanding adaptive capacity, they are frequently not adopted, creating adaptation deficits in agricultural systems (Marshall 2010; Noble et al. 2014).

- Top-down approaches to climate adaptation need to be effectively balanced with bottomup approaches such as learning networks and peer-to-peer support for particular commodities that address both biophysical and socioeconomic considerations at local and regional scales (Noble et al. 2014).

Climate adaptation requires approaches that address biophysical and socioeconomic considerations at regional and local scales, in addition to those already addressing these considerations at national and international scales. As the agricultural community becomes more aware of climate change, they will need new information and technologies to reduce vulnerability of their production systems. The Southern Plains region currently has a strong network of extension and USDA programs to address evolving needs of agriculture. Recently, these resources have been strengthened and expanded through establishment of the USDA Regional Climate Hubs, which were designed to enhance awareness of and access to programs and services within USDA, facilitate regional partnerships, organize training and learning events, and foster producer networks and peer learning to reduce agricultural vulnerability.

Open Access This article is distributed under the terms of the Creative Commons Attribution 4.0 International License (http://creativecommons.org/licenses/by/4.0/), which permits unrestricted use, distribution, and reproduction in any medium, provided you give appropriate credit to the original author(s) and the source, provide a link to the Creative Commons license, and indicate if changes were made.

\section{References}

Acosta-Martínez V, Cotton J, Gardner T et al (2014) Predominant bacterial and fungal assemblages in agricultural soils during a record drought/heat wave and linkages to enzyme activities of biogeochemical cycling. Appl Soil Ecol 84:69-82

Adger WN (2006) Vulnerability. Glob Environ Chang 16:268-281

Ahuja LR, Andales AA, Ma L, Saseendran SA (2007) Whole-system integration and modeling essential to agricultural science and technology for the 21st century. J Crop Improv 19(1-2):73-103

Anandhi A, Steiner JL, Bailey N (2016) A system's approach to assess the exposure of agricultural production to climate change and variability. Clim Chang 136:647-659

Ayres MP, Lombardero MJ (2000) Assessing the consequences of global change for forest disturbance from herbivores and pathogens. Sci Total Environ 262:263-286

Backoulou GF, Elliott NC, Royer TA et al (2014) A web-based decision support system for managing panicle caterpillars in sorghum. Crop Manag 13:0. doi:10.2134/CM-2014-0020-MG

Baker JT, Mahan JR, Gitz DC et al (2013) Comparison of deficit irrigation scheduling methods that use canopy temperature measurements. Plant Biosyst - An Int J Deal with all Asp Plant Biol 147:40-49

Baumhardt RL, Mauget SA, Schwartz RC, Jones OR (2016) El Niño Southern Oscillation effects on dryland crop production in the Texas High Plains. Agron J 108:736

Briske DD, Joyce LA, Polley HW et al (2015) Climate-change adaptation on rangelands: linking regional exposure with diverse adaptive capacity. Front Ecol Environ 13:249-256 
Brown JR, Herrick JE (2016) Making soil health a part of rangeland management. J Soil Water Conserv 71(3): $55 \mathrm{~A}-60 \mathrm{~A}$

Brown-Brandl TM, Eigenberg RA, Nienaber JA, Hahn GL (2005) Dynamic response indicators of heat stress in shaded and non-shaded feedlot cattle, part 1: analyses of indicators. Biosyst Eng 90:451-462

Burke JJ, Chen J (2015) Enhancement of reproductive heat tolerance in plants. PLoS One 10:e122933. doi:10.1371/journal.pone.0122933

Burow G, Acosta Martinez V, Cotton J, et al (2014) Sustainable sorghum cropping systems for flexible forage/ bio-energy use under limited irrigation. In: Proceedings of the Ogallala Aquifer - Steps to Sustainability. p. 8

Climate Change Science Program, CCSP(2008) Preliminary review of adaptation options for climate-sensitive ecosystems and resources (SAP 4.4). Washington, D.C.

Conaty W, Burke J, Mahan J et al (2012) The optimum plant temperature for cotton growth and metabolism to schedule irrigation. Crop Sci 52:1828-1836

Dinon H, Burnett R, Taylor E, et al (2013) Drought and southern forests: the importance of forest health and resiliency. http:/www.sref.info/resources/publications/drought-and-southern-forests-the-importance-offorest-health-and-resiliency Accessed 9/6/16

Eigenberg RA, Brown-Brandl TM, Nienaber JA, Hahn GL (2005) Dynamic response indicators of heat stress in shaded and non-shaded feedlot cattle, part 2: predictive relationships. Biosys Engin 91(1):111-118

Emendack Y, Malinowski D, Burke J et al (2014) Morpho-physiological characterization of cold-and preflowering drought tolerance in grain sorghum (Sorghum bicolor L. Moench) inbreds. Am J Exp Agric 4: $1500-1516$

Engle NL (2011) Adaptive capacity and its assessment. Glob Environ Chang 21:647-656

Fazey I, Gamarra JG, Fischer J et al (2010) Adaptation strategies for reducing vulnerability to future environmental change. Front Ecol Environ 8:414-422

Franzen D, Kitchen N, Holland K et al (2016) Algorithms for in-season nutrient management in cereals. Agron J 108:1775

Hahn GL (1997) Dynamic responses of cattle to thermal heat loads. J Anim Sci 77(suppl_2):10-20

Hatfield JL, Boote KJ, Kimball BA et al (2011) Climate impacts on agriculture: implications for crop production. Agron J 103:351

Hoerling M, Kumar A, Dole R et al (2013) Anatomy of an extreme event. J Clim 26:2811-2832

Hoffmann I (2010) Climate change and the characterization, breeding and conservation of animal genetic resources. Anim Genet 41(Suppl 1):32-46

Howden SM, Soussana J-F, Tubiello FN et al (2007) Adapting agriculture to climate change. Proc Natl Acad Sci U S A 104:19691-19696

IPCC (2014) Climate change 2014: synthesis report. In: Core Writing Team, Pachauri RK, Meyer LA (eds) Contribution of Working Groups I, II and III to the Fifth Assessment Report of the Intergovernmental Panel on Climate Change. IPCC, Geneva 151 pp

Izaurralde RC, Thomson AM, Morgan JA et al (2011) Climate impacts on agriculture: implications for forage and rangeland production. Agron J 103:371

Jin VL, Haney RL, Fay PA, Polley HW (2013) Soil type and moisture regime control microbial C and N mineralization in grassland soils more than atmospheric $\mathrm{CO}_{2}$-induced changes in litter quality. Soil Biol Biochem 58:172-180

Joyce LA, Briske DD, Brown JR et al (2013) Climate change and North American rangelands: assessment of mitigation and adaptation strategies. Rangel Ecol Manag 66:512-528

Kay RNB (1997) Responses of African livestock and wild herbivores to drought. J Arid Environ 37:683-694

Key N, Sneeringer S, Marquardt D (2014) Climate change, heat stress, and US dairy production. In: USDA-ERS Econ. Res. Rep. http://www.ers.usda.gov/publications/err-economic-research-report/err175.aspx. Accessed 9/11/16

Kunkel KE, Stevens LE, Stevens SE, et al (2013a) Regional climate trends and scenarios for the U.S. National Climate Assessment. Part 4. Climate of the U.S. Great Plains. NOAA Technical Report NESDIS 142-4, 82 pp

Kunkel KE, Karl TR, Brooks H et al (2013b) Monitoring and understanding trends in extreme storms: state of knowledge. Bull Am Meteorol Soc 94:499-514

Lal R (2016) Global food security and nexus thinking. J Soil Water Conserv 71:85A-90A

Layden L (2014) Pressure on Arkansas polluters behind recent Illinois River water quality gains. In: StateImpact Oklahoma. https://stateimpact.npr.org/oklahoma/2014/01/16/pressure-on-arkansas-polluters-behind-recentillinois-river-water-quality-gains/ Accessed 3/20/17

Lehman R, Cambardella C, Stott D et al (2015) Understanding and enhancing soil biological health: the solution for reversing soil degradation. Sustainability 7:988-1027

Lui B, Asseng S, Müller C et al (2016) Similar estimates of temperature impacts on global wheat yield by three independent methods. Nat Clim Chang. doi:10.1038/nclimate3115 
Marshall NA (2010) Understanding social resilience to climate variability in primary enterprises and industries. Glob Environ Chang 20:36-43

Mauget SA, Cordero EC (2014a) Optimal ranking regime analysis of intra- to multidecadal U.S. climate variability. Part II: precipitation and streamflow. J Clim 27:9027-9049

Mauget SA, Cordero EC (2014b) Optimal ranking regime analysis of intra- to multidecadal U.S. climate variability. Part I: temperature. J Clim 27:9006-9026

Mbuthia LW, Acosta-Martínez V, DeBruyn J et al (2015) Long term tillage, cover crop, and fertilization effects on microbial community structure, activity: implications for soil quality. Soil Biol Biochem 89:24-34

Mcbride WD, Mathews K (2011) The diverse structure and organization of U.S. beef cow-calf farms. In: Econ. Res. Serv. http://www.ers.usda.gov/Publications/EIB73/EIB73_ReportSummary.pdf Accessed 8/12/16

McGuire V (2011) Water-level changes in the High Plains aquifer, predevelopment to 2009, 2007-08, and 200809, and change in water in storage, predevelopment to 2009. Publ US Geol Surv 18. Reston, VA

McNulty SG, Lorio PLJ, Ayres MP, Reeve JD (1998) Predictions of southern pine beetle populations using a forest ecosystem model. In: Mickler RA, Fox S (eds) The productivity and sustainability of southern forest ecosystems in a changing environment. Springer-Verlag, New York, pp 617-634

Moore GW, Edgar CB, Vogel JG, Washington-Allen RA, March RG, Zehnder R (2016) Tree mortality from an exceptional drought spanning mesic to semiarid ecoregions. Ecol Appl 26:602-611

Mora C, Wei C-L, Rollo A et al (2013) Biotic and human vulnerability to projected changes in ocean biogeochemistry over the 21st century. PLoS Biol 11:e1001682. doi:10.1371/journal.pbio.1001682

Nansen C, Elliott N (2016) Remote sensing and reflectance profiling in entomology. Annu Rev Entomol 61:139158

National Agricultural Statistics Service (2014) 2012 census of agriculture. https://www.agcensus.usda. gov/Publications/2012/ Accessed 6/9/16

Nelson R, Kokic P, Crimp S, Martin P, Meinke H et al (2010) The vulnerability of Australian rural communities to climate variability and change: part II-integrating impacts with adaptive capacity. Environ Sci Pol 13: $18-27$

Nielsen DC, Lyon DJ, Higgins RK et al (2016) Cover crop effect on subsequent wheat yield in the central Great Plains. Agron J 108:243-256

Noble IR, Huq S, Anokhin YA et al (2014) Adaptation needs and options. In: Field CB, Barros VR, Dokken DJ et al (eds) Climate change 2014: impacts, adaptation, and vulnerability. Part A: global and sectoral aspects. Contribution of Working Group II to the Fifth Assessment Report, IPCC. Cambridge University Press, Cambridge and New York, pp 833-868

O’Neill CJ, Swain DL, Kadarmideen HN (2010) Evolutionary process of Bos taurus cattle in favourable versus unfavourable environments and its implications for genetic selection. Evol Appl 3:422-433

O'Reagain P, Bushell J, Holmes B (2011) Managing for rainfall variability: long-term profitability of different grazing strategies in a northern Australian tropical savanna. Anim Prod Sci 51:210

Ojima DS, Steiner J, McNeely S et al (2015) Great Plains regional technical input report. Island Press, Washington, DC, $193 \mathrm{p}$

Otkin JA, Anderson MC, Hain C et al (2016) Assessing the evolution of soil moisture and vegetation conditions during the 2012 United States flash drought. Agric For Meteorol 218:230-242

Parsons CT, Momont PA, Del Curto T et al (2003) Cattle distribution patterns and vegetation use in mountain riparian areas. J Range Manag 56:334-341

Paustian K, Lehmann J, Ogle S et al (2016) Climate-smart soils. Nature 532:49-57

Peck JC (2007) Groundwater management in the High Plains aquifer in the USA: legal problems and innovations. In: Giordano M, Villholth KG (eds) The agricultural groundwater revolution: opportunities and threats to development. Cambridge UP, Cambridge, pp 296-319

Pelling M (2011) Adaptation to climate change: from resilience to transformation. Routledge, New York $274 \mathrm{p}$

Polley HW, Briske DD, Morgan JA et al (2013) Climate change and North American rangelands: trends, projections, and implications. Rangel Ecol Manag 66:493-511

Porter JR, Xie L, Challinor AJ et al (2014) Food security and food production systems. In: Field CB, Barros VR, Dokken DJ et al (eds) Climate change 2014: impacts, adaptation, and vulnerability. Part A: global and sectoral aspects. Cambridge University Press, Cambridge and New York, p 485

Shafer M, Ojima D, Antle JM, et al (2014) Ch. 19: Great Plains climate change impacts in the United States. In: Third Natl. Clim. Assess. https:/www.sciencebase.gov/catalog/item/553e6894e4b0a658d7938957 Accessed $9 / 28 / 16$

Silanikove N (2000) Effects of heat stress on the welfare of extensively managed domestic ruminants. Livest Prod Sci 67:1-18

Steiner JL, Schneider JM, Pope C, et al (2015) Southern Plains assessment of vulnerability and preliminary adaptation and mitigation strategies for farmers, ranchers, and forest land owners. http://www.climatehubs. oce.usda.gov/southernplains. 61 p. Accessed 11/22/2016 
Stewart BA, Steiner JL (1990) Water-use efficiency. In B. A. Stewart, R. P. Singh, and J. F. Parr (eds.). Adv Soil Sci, Springer Verlag, F.R.G. Vol 13:151-173

Sun G, Noormets A, Chen J, McNulty SG (2008) Evapotranspiration estimates from eddy covariance towers and hydrologic modeling in managed forests in northern Wisconsin, USA. Agric Forest Meteor 148:257-267

Thamo T, Addai D, Pannell DJ et al (2017) Climate change impacts and farm-level adaptation: economic analysis of a mixed cropping-livestock system. Agric Syst 150:99-108

Torell LA, Murugan S, Ramirez OA (2010) Economics of flexible versus conservative stocking strategies to manage climate variability and risk. Rangel Ecol Manag 63:415-425

US Geological Survey (2011) National Gap Analysis Program (GAP) version 2. http://gapanalysis.usgs.gov/ Accessed 16 Sep 2016

Van De Water PK, Levetin E (2001) Contribution of upwind pollen sources to the characterization of Juniperus ashei phenology. Grana 40:133-141

Vitale PP, Epplin F, Giles KL et al (2014) Crop diversity on traditional Great Plains wheat farms. J ASFMRA 2014:145-159

Vocke G, Ali M (2013) US wheat production practices, costs, and yields: variations across regions. USDA-ERS, EIB-116 30pp

Volder A, Briske DD, Tjoelker MG (2013) Climate warming and precipitation redistribution modify tree-grass interactions and tree species establishment in a warm-temperate savanna. Glob Chang Biol 19:843-857

Waldrip HM, Pagliari PH, He Z et al (2015) Legacy phosphorus in calcareous soils: effects of long-term poultry litter application. Soil Sci Soc Am J 79:1601-1604

Wang W., S.C. Park, B.A. McCarl. (2011) Economic and groundwater use implications of climate change and bioenergy feedstock production in the Ogallala aquifer region. Agricultural \& Applied Economics Association's AAEA\&NAREA Joint Annual Meeting, Pittsburg, PA. July 24-26, 2011

Wang Y-H, Burow G, Burke J (2014) Genetic mapping of abiotic stress responses in sorghum. In: Genetics. CRC Press, Genomics and Breeding of Sorghum, pp 182-197

Walthall C, Hatfield J, Marshall E, et al (2012) Climate change and agriculture: effects and adaptation. http://www.usda.gov/oce/climate_change/effects_2012/effects_agriculture.htm Accessed 27 Sep 2016

Weindl I, Lotze-Campen H, Popp A, et al (2015) Livestock in a changing climate: production system transitions as an adaptation strategy for agriculture. Environ Res Lett 10(2015)094021

Wilcox BP, Sorice MG, Angerer J, Wright CL (2012) Historical changes in stocking densities on Texas rangelands. Rangel Ecol Manag 65:313-317

Xue Q, Rudd JC, Liu S et al (2014) Yield determination and water-use efficiency of wheat under water-limited conditions in the U.S. Southern High Plains. Crop Sci 54:34-47

Zhang YW, Hagerman AD, McCarl BA (2013) Influence of climate factors on spatial distribution of Texas cattle breeds. Clim Chang 118:183-195 